\title{
Effect of E-Commerce on Organization Sustainability
}

\author{
"Sanjay Chaudhary \\ Associate Professor, Delhi School of Business, AU Block, Outer Ring Road, Pitampura, Delhi, India \\ Corresponding Author: Sanjay Chaudhary
}

\begin{abstract}
This paper establishes the relationship between e-commerce and sustainability factors in the business organizations. The author has also shown the medium to the high positive effect of e-commerce on a clear majority of twenty sustainability factors belonging to environmental, economic, social and general domains as per the opinion survey. Given the effect of e-commerce on sustainability factors, with an overall mean score of 3.61 out of the maximum rating of 5 in an opinion survey, consequently the respondent generally believesthat the e-commerce does have a positive effect on the overall sustainability of an organization. The author suggests e-commerce as one the sustainability development measures that can be implemented by business organizations. The sustainability factors are arranged in the metrics, that can be adopted by a business manager for measuring the extent of the e - commerce effect on the sustainability of a business organization. E-commerce managers may also use the findings of this study to gain further insight into sustainability aspects of e-commerce activities. The author urges businesses to leverage e-commerce to create sustainable solutions that address customer, environmental and societal value expectations. The author has shown in the statistical analysis, that overwhelming majority of the sustainability factors (economic, environmental, social) is positively correlated with each other. Therefore, business practice shall be congruent and compatible with the business initiatives for environmental and social responsibility. Furthermore, the author urges businesses to leverage e-commerce not only for economic reasons, but these activities will also help meet environmental compliance.
\end{abstract}

Keywords: E-commerce, Digital Commerce, Sustainability, Sustainability Metrics, Organizational Sustainability, India.

Date of Submission: 09-06-2017

Date of acceptance: $15-07-2017$

\section{Introduction}

The e-commerce is booming in India with a high number of transactions and monetary value. At the same time, sustainability remains among the top agenda items for companies, government, and consumers. It shall be pertinent, to see the linkage between e-commerce and sustainability at this growth phase before it is too late. The e-commerce industry is to ramp up with ever expanding computer and connectivity mechanisms that have a dramatic impact on day-to-day life (Jayaraman et al., 2013). E-commerce Sales in India, pegged at $\$ 16$ billion in 2015 are the top growing in the world. E-commerce companies like Amazon, Flipkart, Snapdeal, Ebay and PayTM are household names today (Economist, 2016).

Though, we acknowledge the important role e-commerce has in Indian economy where companies are retrofitting warehouses and local shops into new distribution networks. The leapfrogging activities meant for shops, finance and logistics, it is the possibility that the Indian e-commerce model becomes a role-model for emerging markets around the globe. Similarly, India too has a legitimate concern for the environment and increased awareness for global warming. It means that the sustainable management of organization resources and systems is becoming increasingly important (Corbet, 2009). Globally, organizations are labouring to implement environmentally responsible business practices in order to respond to increasing pressure for environmental responsiveness (Henriques and Sadorsky 1999, Ramus and Steger 2000). The beginning of a new paradigm in business is expected, driven by sustainability, integrated economy, environment and society through greater sustainability awareness (Barata et al., 2014). Similar to Green IT perspective, propagated by experts (Molla et al., 2008), e-commerce, sustainability aspect includes initiatives that use e-commerce to change organizational processes, practices to improve energy efficiency and reduce environmental impact; and the introduction of environmentally healthier products and/or services. Business organizations are adopting ecommerce, either without a consideration for sustainability or a holistic approach to sustainability. It shall be useful for business organizations to look at the effect of e-commerce on organization's sustainability factors (financial, environmental and social) and see gains coming out of this. 


\section{Research Objectives And Approach}

The overall purpose of this study is to establish the relationship between e-commerce and sustainability of business organizations. The relationship is found using literature review. Then, the result of opinion survey, shall clarify the majority belief with respect to the effect of e-commerce activities on sustainability factors present in an organization. The result of the study will help the business manager to justify sustainable development and compliance; with e-commerce as a support activity. E-commerce proponents will also get an additional sustainability development point of view. The "business organizations" in this study means small to large sized business organizations in India. The "major factors" are those factors that have high importance in the opinion expressed by survey respondents. The secondary research involvesthe gathering of preliminary information via literature review (research paper, research article, conference papers, research reports, and guidelines) and information synthesis to identify and document e-commerce value chain components. Also, the main constituents (factors) of sustainability in an Organization are identified. In all, fifty-five academic research articles are reviewed, and among them, forty-three are referenced in this research. The primary research includes sampling design and data collection. For convenience, simple random sampling without replacement (SRSWOR) is selected. The sampling unit is working executives or student where every one of them has an equal chance of being selected. Respondent upfront declared that they haveknowledgeabout e-commerce and sustainability. Thus the response from only 65 respondents (out of total 75) who checked yes for both was selected for further analysis. In Data Collection, thesustainabilityfactors identified from the secondary research were reviewed and then an explicit questionnaire was designed (Annexure 2). The questionnaire has 16 questions with a rating scale (1 (Very Low) to 5 (Very High)). From the survey, the data is collected via responses to a questionnaire during a period of one and a half month in May - June2016. The questionnaire is designed by the author, post literature review. The questions are based around the major domains and factors of sustainability metrics. Respondent were 41 students and 34 working executives in the age range of 18-25 yrs. (45 Nos.), 25-40 yrs. (20 Nos.), 40-60 yrs. (10 Nos.) and consisted of 50 males and 25 females.All respondents are from an urban area in Delhi, India.

\section{Literature Review}

There is phenomenal growth in e-commerce industry (Kesavan and Ning, 2014). We have witnessed the prosperity of e-commerce companies, e.g.amazon.com, ebay.com, alibaba.com, Netflix.com, dell.com, staples.com, betbuy.com, apple.com, groupon.com, snapdeal.com, flipkart.com, grofers.com, and makemytrip.com etc. The growth of e-commerce is due to factors, including a wider choice of product/services, easy product/service search, attractive pricing comparable across vendors, convenient anywhere and $24 * 7$ shopping, affordable or no delivery charges, easy return policy, higher customer satisfaction index than traditional stores (Rigby, 2011), reduction in time and cost and no need for agents (Abbad et al., 2011).

The e-commerce companies are deploying not only innovative technology but also innovative business models. In developed nations, e-commerce is the significant determinant of change in selling logistics and physical delivery arrangements (Ionescu, 2014).

The resources are the source of firm competitive advantage (Barney, 1991). In a research on Banking Unit, researcher defined the strategic context of the e-commerce unit as the extent of resource flows to and from the banking unit (Callaway, 2006). They found that the e-commerce creates substantial opportunities for cost reduction and presenting new sources of revenue; banks with a well-developed e-commerce unit will likely demonstrate superior performance; measured by revenue enhancement and cost efficiency (Callaway, 2011).Ecommerce offers a low cost way for banks to expand market reach and product breadth (Pyun et al., 2002).

Beyond the banking industry and in general, by joining the e-commerce, companies reduce communications costs, information collection costs, promotion costs andlabour costs. Other researchers have also recommended e-commerce adoption. The best and the most efficient way for a manager to improve the operations and company performance are to implement new technologies and engage in e-commerce and internet marketing (Kikovska-Georgievska S, 2013).

The author suggests that it is a cascade effect that e-commerce results in more efficient operations processes which often results in higher job satisfaction for employees. The satisfied and motivated employee leads to more satisfied customer and generate better financial results for the organization. Especially in retail business, the expansion of e-commerce is changing the whole game, be it online and multi-channel merchandizing, logistics and supply chain management or providing the better customer experience (JLL, 2013). No wonder, we see that, to improve profits and achieve strategic sustainability in a rapidly changing competitive environment, many online websites have repackaged themselves for e-commerce by targeting new markets, expanding into online and offline world, forming alliances, licensing software and adjusting their core offering to focus on the most profitable products and customers (Chircu et al., 2000).

The author has collated the main components of E-commerce (Jayaraman, 2013) in Table 1. 
Table 1: Main Components of E-commerce

\begin{tabular}{|c|c|c|c|}
\hline S. No. & Component & Processes & Indicators \\
\hline 1 & Supply Chain & $\begin{array}{l}\text { Suppliers, Supplier Relations } \\
\text { Management }\end{array}$ & $\begin{array}{l}\text { No. of suppliers, cost of supplies, delivery adherence, } \\
\text { flexibility to change output and service, comprehensive } \\
\text { product line, quality of output, meeting business needs. }\end{array}$ \\
\hline 2 & Logistics & $\begin{array}{l}\text { Distributors / Logistics } \\
\text { companies }\end{array}$ & $\begin{array}{l}\text { Warehouse locations, reach, the efficiency of } \\
\text { performance like delivery adherence, defect free supply, } \\
\text { reverse supply chain abilities. }\end{array}$ \\
\hline 3 & $\begin{array}{l}\text { InformationTechnology } \\
\text { (IT) }\end{array}$ & ICT Applications & $\begin{array}{l}\text { Internet networks, software, and hardware, cloud } \\
\text { computing, e-catalogues, e-marketplaces. Automating } \\
\text { and transforming products, business processes and } \\
\text { relationships (supplier relationship management, } \\
\text { customer relationship management, order management, } \\
\text { delivery management). }\end{array}$ \\
\hline 4 & Commercial & Internal Processes & $\begin{array}{l}\text { Order tracking, delivery tracking, stocking and inventory } \\
\text { management, customer complaints handling, web } \\
\text { maintenance, pricing and terms of offer, daily } \\
\text { management }\end{array}$ \\
\hline 5 & Markets & $\begin{array}{lr}\text { Customer, } & \text { Customer } \\
\text { Relationship Management, } \\
\text { Market information }\end{array}$ & $\begin{array}{l}\text { Customer data capture and analytics, customer } \\
\text { preferences, competition activities, new channels for } \\
\text { meeting demand }\end{array}$ \\
\hline 6 & Stakeholders & External situation & $\begin{array}{l}\text { Regulations, banking and payment methods, cyber laws, } \\
\text { taxes, government filings }\end{array}$ \\
\hline
\end{tabular}

At the individual decision maker, if relevant to business, e-commerce shall be accepted. So much so, the researcher has quoted that if the manager wants to keep the company sustainable in long to midterm, he has no other choice but to join new trends of doing business via e-commerce (Kikovska-Georgievska S, 2013).

As organizations develop e-commerce strategy, it is important to have participation from various stakeholders in planning and implementing e-commerce initiatives.As all core aspects of an organization system, including operations, procurement and delivery are involved in e-commerce at the same time they all are influenced by the requisite need to safeguard and protect the environment (Kliendorfer et al., 2005). Thus, e-commerce initiatives shall have focus both on environmental and economic indicators. There is nothing to lose, since environmental performance influences economic performance (Ryoo and Koo, 2013), this may motivate firms to participate in green practices (Vachon and Klassen, 2006) e.g. for top 100 companies in India, 54\% (27 out of 50) of the private companies and $42 \%$ ( 21 out of 50) of the public companies had an impact on their performance by doing green management (Pillania, 2012).

While adopting e-commerce, it is equally important for organizations to encourage business practices to be congruent and compatible with their initiatives for environmental responsibility (Jenkins et al., 2011). Interest in environmental aspect has increased tremendously in recent time, such that the focus is progressively shifting from wide-ranging environmental effects of e-commerce to the need for the quantitative evaluation of their impact (Riccardo et. al., 2015).

The various forms of e-commerce e.g. e-procurement plays an important role in the sustainability of streamlining and optimizing the whole supply chain (Lysons and Farrington, 2012). Also, the sustainable operations management assimilates the turnover and efficiency orientation with broader deliberations of the organization's stakeholders and its environmental impact (Kliendorfer et al., 2005; Bettley and Burnley, 2008) The authorsuggests that obvious e-commerce effect on sustainability may include energy efficiency of cloud computing and IT usage, dematerialization (aka digitalization) and collaborationtechniques (CRM, chats, click to call), reducing travel (video-conferencing, click to order) and improved supply chain efficiency. But, this is not exhaustive. Author, when tried, to look at macro aspects, find that the progressively broad range of services provided by retail merchants brings about transformation in the design of urban transportation flows and vehicle activities in cities (Popescu et al, 2014, Visser et al, 2014).Due to environmental influence and new traffic generated by e-commerce, distribution and home deliveries, we see the logistics strategies are being adjusted by major consumer companies to meet the new to the demands of urban zones.

At the social level, the author tried to find examples similar to e-chaupal by vendor ITC in India. We find the example of SAP organization which is working with South African rural communities. The mobile procurement solution enables local shop owners to SMS their supply orders which in turn improve the availability of goods in villages. Other vendors, Google and Microsoft have put their data centre in rural areas, partly powered by local alternative energy, thus contributing financially to the local community (Jain, Fitch, and Kannan, 2011). One major component of e-commerce is an Information Technology (IT). E-commerce unit uses existing critical IT resources to launch the e-commerce, then this unit can be used to develop IT capabilities across the organization to leverage the potential of IT (Callaway and Jagani, 2015). When IT is aligned positively with environmental practices (part of sustainability) it also affects the environmental coordination of manufacturing and marketing (Ryoo and Koo, 2013). The green movement with IT has become a priority for 
companies, NGOs, and even consumers, all over the world (Forrester 2009, Mingay 2009, and Schumpeter 2011). According to Forrester research, $38 \%$ of surveyed companies indicated that IT plays a central role in corporate sustainability efforts (Schultz 2010). There is a high usage of IT in e-commerce, which increases the IT capital proportion in business. The high IT capital proportion effect the production oriented initiative of sustainable effectiveness, sustainable inferences of e-business resolutions, and e-commerce impacts on social sustainability (Popescu G. H., 2015). Nowadays, IT is enabling the next generation of technology convergence that will impact the sustainability of infrastructure systems e.g. Buildings, supply chains, transportation networks or entire cities (Lee et al, 2010).IT based new approaches and technologies help companies to become energy efficient, reducethe carbon emission, avoid the wastage of resource, reduce the usage of resources (Faucheux and Nicholai 2011, Mullich 2011) and prevent air, water, and soil pollution

IT support more efficient use of energy on appliances, products, buildings, manufacturing and transportation monitoring information on the environment throughout the supply chain and help develop product and services that impose lower carbon footprint and redesigning a variety of life and working style such a telecommuting, education, entertainment, shopping, transportation and recycling (Trimi Silvana and Park Sang Hyun, 2012). In future, IT-enabled solutions that use technologies such as sensors and RFID tagswill monitor and improve the use of various resources (human, water, electricity etc.) And such solution incorporates data analytics tools to analyze organizations footprint and reducing the environmental impact. Having reviewed the literature on e-commerce and its linkage with the sustainability, it may be pertinent to look at the sustainability and its measure. Why we want this, is because the metrics shall be developed using this information. The author finds that the one of the most common interpretation of sustainability is the triple bottom line (TBL) concept. The TBL states that sustainable development must comprise the social, environmental and economic dimensions (Elkington, 1997, Slaper and Hall, 2011). TBL is getting good attention and adoption across businesses. Its adoption is a significant step towards integrating sustainability-related metrics into overall performance; organizations haven't adequately balanced economic, social and environmental components into their performance measures (Jain, Fitch and Kannan, 2011). To resolve the complexity around sustainability author reviewed the literature for a simple metric that can combine multiple functions and can be applied across multiple organizations. The author finds that the global reporting initiative (GRI) sustainability guideline on economic, environmental and social performance (GRI, 2000) is such a metrics that include financial and social criteria. It also distinguishes "sustainability" reporting from just environmental reporting. In GRI 2000 reporting guidelines, the topics are arranged in eight categories, the first five if which deals with various management and policy considerations and the last three with performance (Morhardt et al., 2002). The eight categories are shown in Table 2.

Table 2: GRI Guidelines Categories

\begin{tabular}{|l|l|l|}
\hline \multicolumn{1}{|c|}{ S. No. } & \multicolumn{1}{|c|}{ Category } & \multicolumn{1}{c|}{ Topics } \\
\hline 1 & General Organization Features & 43 \\
\hline 1.1 & CEO statement & 5 \\
\hline 1.2 & Organizational Profile & 15 \\
\hline 1.3 & Key Indicators & 5 \\
\hline 1.4 & Vision and Strategy & 4 \\
\hline 1.5 & Policies, Organization, and Management Systems & 14 \\
\hline 2 & Environmental Performance Metrics & 36 \\
\hline 3 & Economic Performance Metrics & 23 \\
\hline 4 & Social Performance Metrics & 37 \\
\hline
\end{tabular}

Based on the above literature review, Author proposes a metrics to analyse the effect of E-Commerce on Sustainability. The preliminary metrics with four domains and seventeen factors is shown in Table 3 . The few factors are logically acceptable as emanating from using e-commerce e.g. less travel, lower inventory, less paper use in printing and packaging, less wastage and digital delivery, yet others were selected from TBL, GRI guidelines and, literature review. The e-commerce shall affect the various factors of sustainability to a variable degree; if we can justify the extent of effect by primary research it shall be useful to shortlist the important factors which shall be paid more attention. The metrics can be also used as a decision-aiding tool for sustainable e-commerce governance.

Table 3: Sustainability Domains and Factors

\begin{tabular}{|c|l|l|}
\hline S. No. & Sustainability Domain & \multicolumn{1}{c|}{ Factors } \\
\hline I & Environmental Domain & \\
\hline 1 & & Reduction in energy consumption \\
\hline 2 & & Reduction in Natural Resource Consumption \\
\hline 3 & & Improved use of renewable energy \\
\hline 4 & & Reduction in Waste \\
\hline 5 & & Optimizing Material Usage \\
\hline 6 & & Improved and efficient usage of resources \\
\hline 7 & & Reducing Reverse logistics - product reacquisition and remarketing \\
\hline
\end{tabular}


Effect Of E-Commerce On Organization Sustainability

\begin{tabular}{|l|l|l|}
\hline 8 & & Improving Reverse logistics - product reacquisition and remarketing \\
\hline II & Economic Domain & \\
\hline 9 & & Technology improvement leading to energy efficiency \\
\hline 10 & & Long term financial competitiveness \\
\hline 11 & & Better Cost efficiency \\
\hline 12 & & Improved Market presence \\
\hline III & Social Domain & \\
\hline 13 & & Engage all staff in carbon- neutral improvement activities \\
\hline 14 & & Draw supplier and partners attention to the environmental credentials \\
\hline 15 & & Better job security \\
\hline 16 & & Improved ethical behaviour \\
\hline IV & General Domain & \\
\hline 17 & & Use of green metrics in assessing business processes \\
\hline 18 & & $\begin{array}{l}\text { Supply chain to include design, dealing with by-products and end of life } \\
\text { processes of recovery and disposal }\end{array}$ \\
\hline 19 & & Respect for international norms and behaviours \\
\hline 20 & & Reducing product reacquisition and remarketing \\
\hline
\end{tabular}

\section{Research Findings}

The literature review and analysis, uncovers the need for to further establish and validate the ecommerce and organization's sustainability metrics (Table 3). For this, an opinion survey is done. The purpose of opinion survey is to gauge the effect of e-commerce on the various factors of sustainability. The opinion survey also helps shortlist the sustainability factors which are most affected by e-commerce. The opinion survey captures each of the response on a scale of 1 to 5 rating to gauge the extent of the effect. The factors with high mean scale rating are more affected by e-commerce thus needs more attention or monitoring. The result of statistical analysis of 65 valid opinion survey responses shows that, with an overall mean score of 3.61 out of 5, the e-commerce does have a positive effect onthe sustainability of an organization. Data distribution is slightly negatively skewed (more responses having large values) and kurtosis is also slightly leptokurtic (more peaked). Looking at effect on e-commerce on each sustainability factor, the respondent agreed with a mean score of 4.09 out of 5, the e-commerce has a high effect on the financial competitiveness of a business organization. Among top 5, the other factors that got most affected by e-commerce are improvement of cost efficiency (3.98), technology improvement leading to energy efficiency improvement (3.89), improved market presence (3.95), improved and efficient usage of resources (3.85) and reducing waste (3.82). Further detail is shown in Table 4.

Table 4: Mean Scores of Opinion Survey Responses

\begin{tabular}{|l|l|l|l|l|}
\hline Effect on Sustainability Factor & Mean & Std. Deviation & Skewness & Kurtosis \\
\hline Effect of E-commerce on reducing energy consumption & 3.72 & .839 & -.416 & -.231 \\
\hline $\begin{array}{l}\text { Effect of E-commerce on reducing natural resource } \\
\text { consumption }\end{array}$ & 3.63 & .840 & -.346 & -.349 \\
\hline Effect of E-commerce on reducing wastage & 3.82 & .917 & -.624 & -.256 \\
\hline Effect of E-commerce on optimizing material usage & 3.74 & .906 & -.490 & .200 \\
\hline $\begin{array}{l}\text { Effect of E-commerce on improved and efficient usage of } \\
\text { resources }\end{array}$ & 3.85 & .905 & -.989 & 1.004 \\
\hline Effect of E-commerce on improving reverse logistics & 3.66 & .735 & -.097 & -.193 \\
\hline Effect of E-commerce on reducing reverse logistics & 3.31 & .900 & -.260 & .160 \\
\hline $\begin{array}{l}\text { Effect of E-commerce on reducing product reacquisition } \\
\text { and remarketing }\end{array}$ & 3.60 & .997 & -.285 & -.518 \\
\hline $\begin{array}{l}\text { Effect of E-commerce on bringing reforms in operational } \\
\text { practices to engage all staff in carbon-neutral improvement } \\
\text { activities }\end{array}$ & 3.55 & .902 & -.166 & -.688 \\
\hline Effect of E-commerce on job security & & & \\
\hline $\begin{array}{l}\text { Effect of E-commerce on encouraging operations to add } \\
\text { green metrics to the measures of assessment }\end{array}$ & 3.52 & 1.032 & -.312 & -.644 \\
\hline $\begin{array}{l}\text { E-commerce pay attention to the environmental credential } \\
\text { of all its suppliers and partners }\end{array}$ & 3.22 & 1.008 & -.327 & -.730 \\
\hline E-commerce increase use of renewable energy & 3.17 & 1.009 & -.073 & -.653 \\
\hline $\begin{array}{l}\text { E-commerce on improved end of life processes of } \\
\text { recovery and disposal of products }\end{array}$ & 3.38 & .913 & -.163 &.- .515 \\
\hline Effect of E-commerce on cost efficiency & 3.98 & .780 & -.472 & .122 \\
\hline Effect of E-commerce on financial competitiveness & 4.09 & .879 & -.380 & -.267 \\
\hline $\begin{array}{l}\text { Effect of E-commerce on technology improvement leading } \\
\text { to energy efficiency improvement }\end{array}$ & 3.89 & .937 & -.611 & -.473 \\
\hline Effect of E-commerce on improved market presence & 3.95 & .837 & -.484 & -.604 \\
\hline Effect of E-commerce on ethical behaviour & 3.40 & .898 & -.406 & -.432 \\
\hline $\begin{array}{l}\text { Effect of E-commerce on respect to international norms } \\
\text { and behaviour }\end{array}$ & 3.58 & .967 & -.625 & -.407 \\
\hline & & & .243 \\
\hline
\end{tabular}


In addition, the Correlation analysis of responses is done to see the sympathetic movement and direction of the factors. The correlation coefficient degree varies between +1 (maximum) and -1 (minimum) and direction positive (+) means favourable while negative (-) means unfavourable. The result of correlation analysis (at, $1 \%$ and 5\% significant level) is shown in Table 5 (Annexure 1). Most of the various e-commerce effects on the sustainability factors are positively correlated with each other as expected, barring 39 out of 400 which are also not significant at $1 \%$ or $5 \%$. Thus we can use these correlated factors in our metrics to gauge the overall effect on sustainability or overall sustainability level. At the $1 \%$ significance level, we look at the significant correlation of the major factors as identified in the opinion survey. This shall be useful while looking at synergy effect as well as other factors that shall be given attention if a business manager goes by 80-20 principal. In the economic domain, the e-commerce effect on financial competitiveness is significantly correlated with effect on cost efficiency (0.549) and improved market presence (0.409). In turn, the e-commerce effect on cost efficiency is significantly correlated with e-commerce contributing to reducing wastage $(0.367)$ and e-commerce helping in the improved market presence (0.334). The e-commerce, helping in the improved market presence is significantly correlated with e-commerce contribution to reducing energy consumption (0.404), reducing product reacquisition and remarketing (0.446) and improving financial competitiveness (0.409).

In the environment domain, the effect on improved and efficient usage of resources is significantly correlated with reduction in wastage (0.342), effect on encouraging operations to add green metrics to the assessment measures (0.388), improved end of life processes of recovery and disposal of products (0.318) and positive effect on respect of international norms and behaviour (0.408). The e-commerce help reduction in wastage is significantly correlated with e-commerce contributing to reducing natural resource consumption (0.336), Improved and efficient usage of resources (0.342) and effect on cost efficiency (0.367). The factor ecommerce helps in reducing natural resource consumption is significantly correlated with e-commerce Reducing energy consumption (0.452), reducing wastage $(0.336)$ and e-commerce leading to technology improvement leading to energy efficiency (0.405). Similarly, the factor e-commerce reduces energy consumption is significantly correlated with e-commerce contributes to reducing natural resource consumption $(0.452)$, ecommerce optimizes material usage (0.356), e-commerce helps in technology improvement leading to energy efficiency (0.350), e-commerce, encouraging operations to add green metrics to the assessment measures (0.332) and e-commerce helping in the improved market presence $(0.404)$. Whereas, e-commerce effect on increased use of renewable energy is significantly correlated with e-commerce, helping in reducing natural resource consumption (0.481), getting attention to the environmental credential of suppliers and partners (0.486), and e-commerce technology improvement leading to energy efficiency (0.350). E-commerce technology improvement leading to energy efficiency is significantly correlated with e-commerce, reducing energy consumption (0.359), reducing of natural resource consumption (0.405), reducing product acquisition and Remarketing (0.321), an increase in the use of renewable energy (0.350), e-commerce helping in the improved market presence $(0.332)$ and respect to international norms and behaviour $(0.309)$.

On the social side, the e-commerce, bringing reforms in operational practices to engage all staff in carbon-neutral improvement activities are significantly correlated to effect on reducing product acquisition and Remarketing (0.372), encouraging operations to add green metrics to the assessment measures (0.372) and increased use of renewable energy (0.342). Similarly, the e-commerce effect on ethical behaviour is significantly correlated to increased respect to international norms and behaviour (0.429) which in turn is significantly correlated with e-commerce optimizing material usage $(0.427)$, improved and efficient usage of resources (0.408), improvement in end of life processes of recovery and disposal of products $(0.343)$, and ecommerce technology improvement leading to energy efficiency $(0.329)$.

\section{Conclusion}

Based on statistical analysis of opinion survey, with a mean score of 3.61 out of maximum rating of 5 , the author has shown that the respondent generally believes that the e-commerce does have a positive effect on the overall sustainability of an organization. In addition, the opinion survey has also shown the pre-dominantly medium to high positive effect of e-commerce on twenty sustainability factors belonging to environmental, economic, social and general domains. Given this, the business organizations shall develop a holistic approach to sustainability and adopt e-commerce not only for economic reasons but also for environmental and social reasons. If it means a change in policies and procedures, so be it.

Businesses must leverage e-commerce to create sustainable solutions that address customer, environmental and societal value expectations. In the short term, e-commerce with sustainability concern may increase operating cost, but result in the midterm reduction in operating cost plus long-term flip to innovation. The innovation may be in new technologies, products, services, processes and business model (Harmon and Demirkan, 2011), thus a major thrust to organizations' competitiveness. 
It is also important for organizations to encourage business practices (particularly e-commerce, supplychain, Information Technology) to be congruent and compatible with their initiatives for environmental responsibility (Jenkins et al., 2009). The author has shown in the statistical analysis, that overwhelming majority of the sustainability factors (economic, environmental, social) is positively correlated with each other. A number of significant correlations exist between major factors leading to possibly a synergy effect. The metrics shown in Table 3 could be a starting point to gauge the overall effect of e-commerce on the sustainability of a business organization.The integration of major sustainability factors in e-commerce set-up and close attention to their management shall help boost the triple bottom line of the business organization as well as help meet the sustainability-related compliances. On how organizations approach the development of sustainable e-commerce program, it shall be useful to look at the study of drivers behind the game-changing Megatrends (Lubin and Esty, 2010). The study identified four stages in company's migration to trend adoption, e.g. reduces costs, reengineer products and processes, transform the core business, and create new business models. The same shall be applicable to the adoption of sustainable e-commerce.

Due to time and resource limitations, the study is in narrow setting and; hence, the findings and conclusion may be reflective of Indian demography, relatively younger population and Delhi NCR based business perspective only. A similar future study on e-commerce initiatives in a particular Industry vertical or a particular e-commerce initiative shall be able to give highly interesting and quantifiable results, e.g. Using egrocery shopping, it is theoretically possible to reduce the greenhouse gas emissions generated by grocery shopping by $18 \%$ to $87 \%$ (Siikavirta et al., 2003) or the Swiss online grocer LeShop.ch, calculated that each time a customer decides to buy online rather than go shopping by car, $3.5 \mathrm{~kg}$ of $\mathrm{CO} 2$ emissions are saved (Chaffey Dave, 2013).

\section{References}

[1] Abbad Muneer, Abbad Rami and Saleh Malik (2011), Limitations of e-commerce in developing countries: Jordan case, Education, Business and Society: Contemporary Middle Eastern Issues, 4(4), 280-291.

[2] Barata José Felipe Figueiredo, Osvaldo Luiz Gonçalves Quelhas, Helder Gomes Costa, Ruben Huamanchumo Gutierrez, Valdir de Jesus Lameira and Marcelo J. Meiriño (2014), Multi-Criteria Indicator for Sustainability Rating in Suppliers of the Oil and Gas Industries in Brazil, Sustainability, 6, 1107-1128

[3] Bettley A. and Burnley S. (2008), Towards Sustainable Operations Management Integrating Sustainability Management into Operations Management Strategies and Practices, Handbook of Performability Engineering, Springer, London, UK.

[4] CallawayS. K. (2011), Internet banking and performance: the relationship of web site traffic rank and bank performance. American Journal of Business, 26, 12-25.

[5] Callaway S. K. (2006), Strategic context for bank units: Comparing resource flows for Internet ventures and traditional branches, The Journal of High Technology Management Research, 17(1), 115.

[6] Callaway, Stephen Kent and Jagani, Sandeep Bhailalbhai (2015), Strategic Context for Internet Banking: How Traditional Banks Manage ecommerce to Build IT Capabilities and Improve Performance, Journal of Internet Banking \& Commerce, 20 (1), 122.

[7] Chaffey David (2013), E-business and E-Commerce Management, India, Dorling Kindersley Pvt. Ltd., 212-213

[8] Chircu, A.M., Davis, G.B., and Kauffman, R.J. (2000),'Trust, expertise, and e-commerce intermediary adoption, Proceedings of the 2000 Americas Conference on Information Systems

[9] Choy KL, Lee WB and Lo V (2004), An enterprise collaborative management system-A case study of supplier relationship management, Journal of Enterprise Information Management, 17(3), 191-207.

[10] Corbet L. M. (2009), Sustainable operations management: A typological approach. Journal of Industrial Engineering and Management, 2(1), 10-30

[11] Economist (2016), E-commerce in emerging markets: India online, the battle for India's e-commerce market is about much more than retailing. Retrieved on June 3, 2016, Retrieved from http://www.economist.com/news/leaders/21693925-battle-indias-ecommerce-market-about-much-more-retailing-india-online

[12] Elkington John (1997), Cannibals with Forks: The Triple Bottom Line of Twenty-First Century Business, Capstone, Oxford.

[13] Faucheux, S. and Nicholai, I. (2011), IT for Green and Green IT: A proposed typology of eco-innovation, Ecological Economics, 70(11), 2020-2027.

[14] Gheorghe H. Popescu (2015), E-commerce effects on social sustainability, Economics, Management, and Financial Markets, 10(1), 80-85.

[15] Global Reporting Initiative (2000), Sustainability Reporting Guidelines on Economic, Environmental, and Social Performance, GRI, Boston

[16] Harmon, Robert R. and Haluk Demirkan (2011), “The Next Wave of Sustainable IT,” IT Professional, IEEE Computer Society, January/February, 19-25. Lead article.

[17] Henriques I., P. Sadorsky (1999), The Relationship Between Environmental Commitment and Managerial Perceptions of Stakeholder Importance, Academy of Management Journal, 42(1), 87-99

[18] Ionescu L. (2014), the adverse effect of corruption on growth and development, Economics, Management and Financial Markets, 9(4), 125-130.

[19] BarneyJ. (1991), Firm resources and sustained competitive advantage, Journal of Management, 17, 99-120.

[20] Jain Radhika P., Benbunan-Fich Raquel and Mohan Kannan (2011), Assessing Green IT Initiatives Using the Balanced Scorecard, Green IT, 11, 26-32.

[21] Jenkins, Beth and Gradl Christina (2011), Tackling Barriers to Scale: From Inclusive Business Models to Inclusive Business Ecosystems, Cambridge, MA, the CSR Initiative at the Harvard Kennedy School

[22] JLL (2013), E-commerce booms triggers transformation in retail logistics: driving a global wave of demand for new logistics facilities, Chicago, IL, JLL

[23] Kesavan Ram and Wei Ning (2014), Sustainability of E-Commerce: The Case of Penny Auctions, International Management Review, 10(2), 49-73. 
[24] KikovskaGeorgievska Sanja (2013), Ecommerce challenge for the sustainable development of Companies, Journal of Sustainable Development, 4 (7), 7183-96.

[25] Kleindorfer PR, Singhal K and Wassenhove LNV (2005), Sustainable operations management, Production and Operations Management,14(4), 482-492.

[26] Lysons Kenneth and Farrington Brians (2012), Purchasing and Supply Chain Management, Pearson, 8.

[27] Morhardt JE, Baird S and Freeman K. (2002), Scoring corporate environmental and sustainability reports using GRI 2000, ISO 14031, and other criteria, Corporate Social Responsibility and Environmental Management, 9, 215-233.

[28] Mullich J (2011), on the verge of new technology: convergence technologies make for some strange sustainability-minded bedfellows, Wall Street Journal

[29] Popescu G. H. (2014), Labor market regulation and the shadow economy, Economics, Management and Financial Markets, 9(3), 110-115.

[30] Popescu, Gheorghe H. (2015), Ecommerce Effects on social sustainability, Economics, Management \& Financial Markets, Vol. 10 (1), 80-85.

[31] Pyun, C. S., Scruggs, L., and Nam, K. (2002), Internet banking in the US, Japan and Europe, Multinational Business Review, 10, $72-81$.

[32] R Jayaraman, Akash Srivastava, Ajit Balgi, Arun Kumar V, Baidyanath Prasad (2013), A Study of Operating Practices and Supply Chains in the e-Commerce Online RetailBusinesses in India, Journal of Supply Chain Management Systems, 2, 33-47.

[33] Pillania Rajesh K(2012), Why \& performance impact of green management \& sustainability in India, Journal of Advances Research in Management, 3 1(5), 46-58.

[34] Ramus, C., and Steger, U. (2000), the role of supervisory support behaviours and environmental policy in employee eco-initiatives at leading-edge European companies, Academy of Management Journal, 43(4), 605-626.

[35] Rigby D. (2011), The Future of Shopping, Harvard Business Review, Retrieved from https://hbr.org/2011/12/the-future-of-shopping

[36] Sang M. Lee, Sang-Hyun Park and Silvana Trimi (2013), Greening with IT: practices of leading countries and strategies of followers. Management Decision, 51(3), 629-642.

[37] Schultz R. A. (2010), IT enabled globalization and the environment, Information technology and the ethics of globalization: Transnational issues and implications, Hershey, PA, 208-22

[38] Siikavirta H., Punakivi M., Karkkainen M. and Linnanen L. (2003), Effects of e-commerce on greenhouse gas emissions: a case study of grocery home delivery in Finland, Journal of Industrial Ecology, 6 (2), 83-97

[39] Silvana Trimi and Sang-Hyun Park (2013), Green IT: practices of leading firms and NGOs, Serv Bus, 7, 363-379.

[40] Slaper Timothy F. and Hall Tanya J. (2011), the Triple Bottom Line: What Is It and How Does It Work, Indiana Business Review, $86(1), 4-8$

[41] Sung Yul Ryoo and Chulmo Koo (2013), Green practices-IS alignment and environmental performance: The mediating effects of coordination, Information System Front, 15, 799-814.

[42] Stephan Vachon, Robert D. Klassen (2006), Extending green practices across the supply chain: The impact of upstream and downstream integration, International Journal of Operations \& Production Management, 26 (7), 795 - 821.

[43] Visser Johan, Toshinori Nemato and Michel Browne (2014), Home delivery and the impact on urban freight transport: a review, Procedia - Social and Behavioural sciences, 125, 15-17

\section{ABOUT AUTHORS}

Sanjay Chaudhary is Associate Professor of MIS and Operations Management at the Delhi School of Business (DSB), VIPS. Prior to DSB, he has twenty years of international work experience in the ICT Industry. An IIT, SUNY and AIT alumnus, he has expertise in Telecom, IT Management, Corporate Management and Training industry.He is awarded a fellowship by the IETE and a Chartered Engineer designation by the Institution of Engineers, India. A fitness enthusiast, he has authored one book, ten magazine articles and one international journal research papers. 
ANNEXURE 1

Table 5: Correlation Analysis of Sustainability Factors

\begin{tabular}{|c|c|c|c|c|c|c|c|c|c|c|c|c|c|c|}
\hline 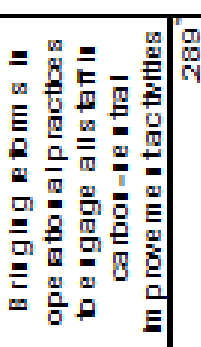 & & 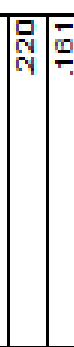 & & Da & $\frac{1}{5}$ & & 递部 & 7 & F & 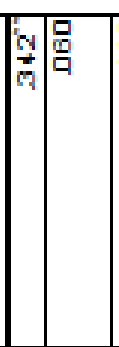 & 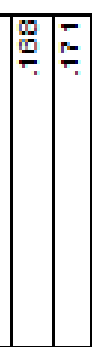 & 象 & & 递 \\
\hline 的事 & 总 & 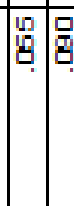 & $\bar{\sigma}$ & 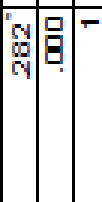 & 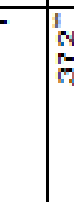 & & 商: & 居 & 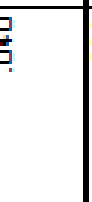 & 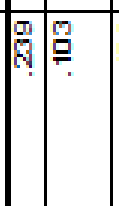 & $\frac{2}{7}$ & $\overline{\mathrm{g}}$ & 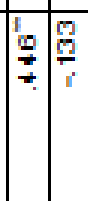 & $\frac{\pi}{a}$ \\
\hline 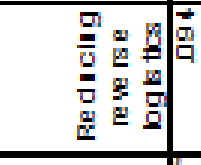 & $\bar{F}$ & $\frac{0}{7}$ & $\overline{1}$ & $\sqrt{-\bar{F}^{-}}$ & $\overline{8}$ & & 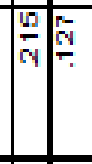 & 兽 & & 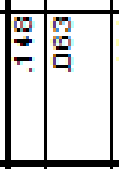 & $\vec{\nabla}$ & $\begin{array}{l}0 \\
1\end{array}$ & & 畗 \\
\hline 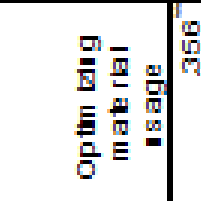 & $\begin{array}{l}0 \\
0\end{array}$ & $\frac{9}{7}$ & 駦 & & 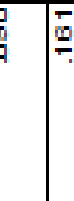 & & 吅象 & ?్ & 5 & 榕 & & 岱 & & $\bar{\pi}$ \\
\hline 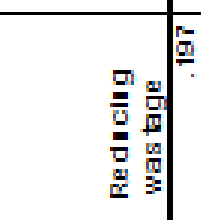 & 尊 & & $\frac{1}{17}$ & & จุ & & 䛎 & $\mathrm{N}$ & F & $\frac{\pi}{2}$ & & \begin{tabular}{|l|l}
0 \\
\end{tabular} & 局 & i⿱ \\
\hline 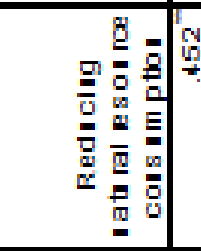 & & 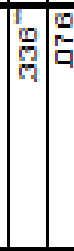 & 居 & $=0$ & & $\frac{2}{n}$ & 商: & สู & N & $\overline{0.00}$ & 溇 & 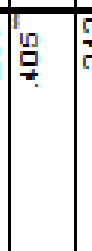 & N) & 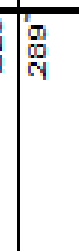 \\
\hline 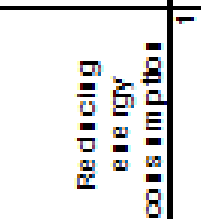 & 番 & & & & 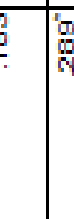 & i & প্লে & 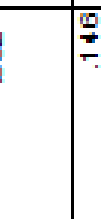 & 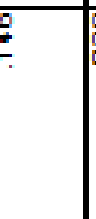 & 器 & 言说 & $\frac{8}{8}$ & $\frac{7}{7}$ & $\mathbb{A}$ \\
\hline 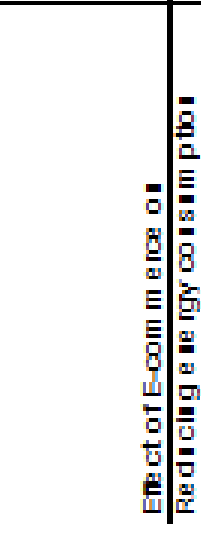 & & 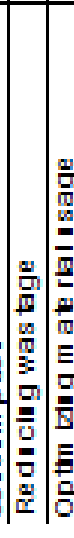 & 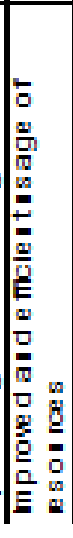 & 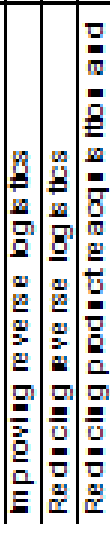 & 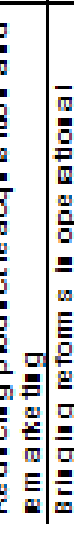 & 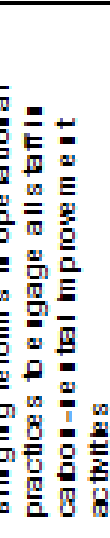 & 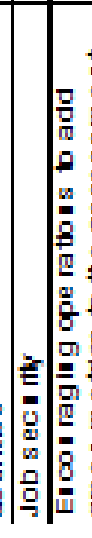 & 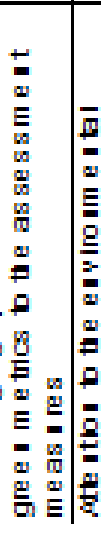 & 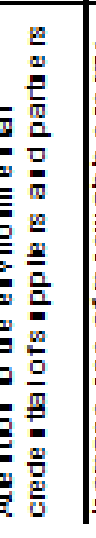 & 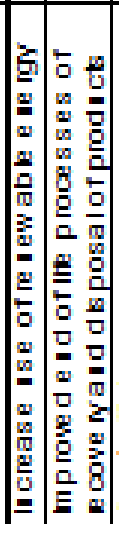 & 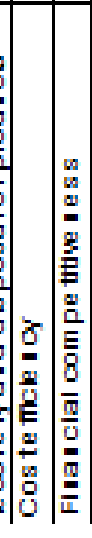 & 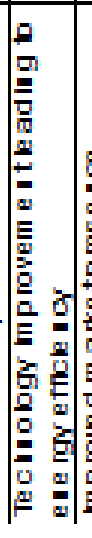 & \begin{tabular}{|l|l|} 
\\
\\
\end{tabular} & 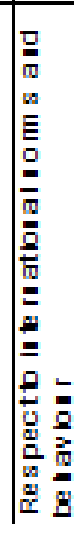 \\
\hline
\end{tabular}




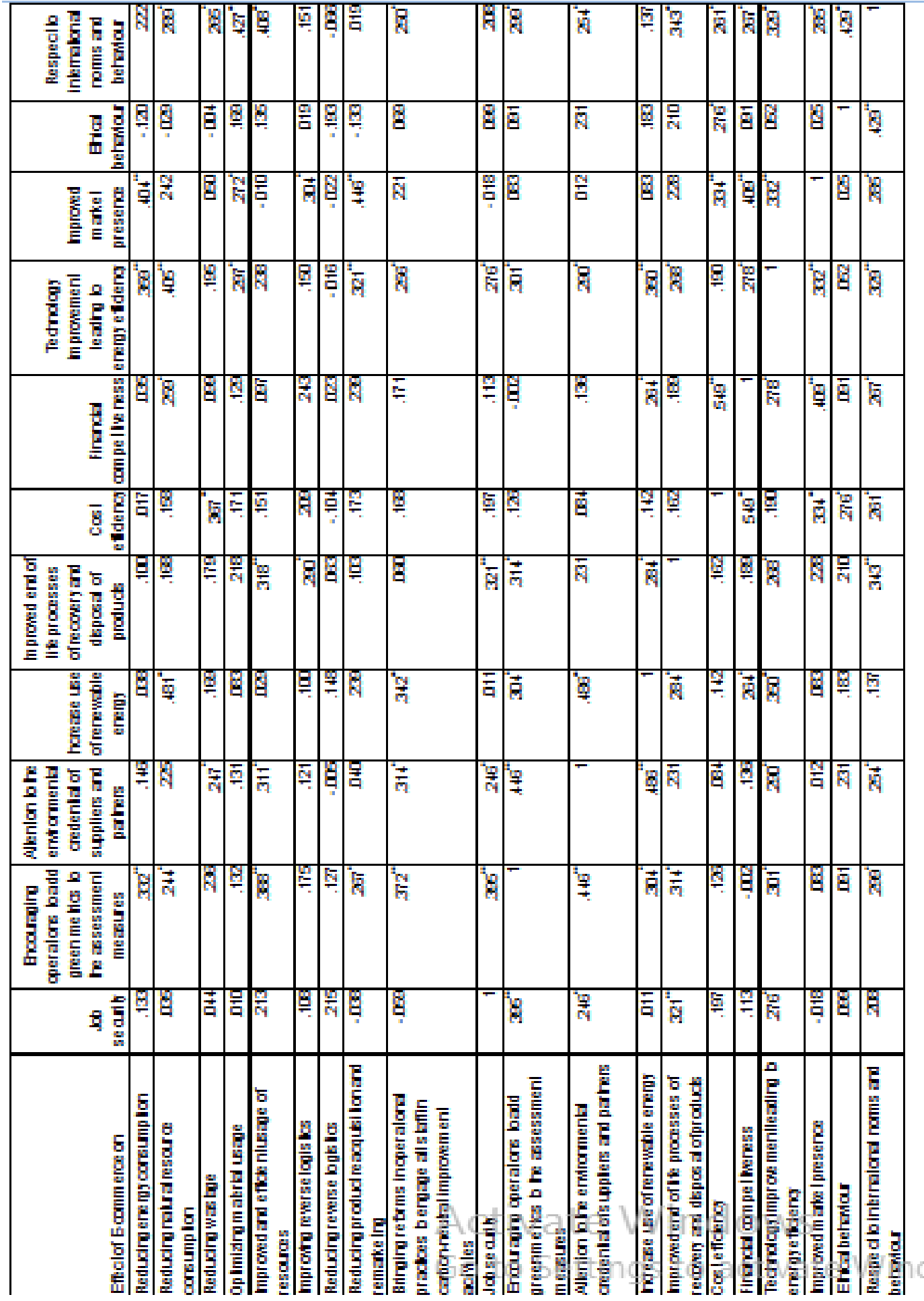

IOSR Journal of Business and Management (IOSR-JBM) is UGC approved Journal with Sl. No. 4481, Journal no. 46879.

Sanjay Chaudhary. "Effect of E-Commerce on Organization Sustainability." IOSR Journal of Business and Management (IOSR-JBM) 19.7 (2017): 15-24. 